\title{
MIGRATION-ENHANCED EPITAXY OF THIN GaAsBi LAYERS
}

\author{
R. Butkutè ${ }^{\text {a }}$, V. Pačebutas ${ }^{a}$, A. Krotkus ${ }^{\text {a }}$, N. Knaub ${ }^{\text {b }}$, and K. Volz ${ }^{b}$ \\ ${ }^{\mathrm{b}}$ Center for Physical Sciences and Technology, A. Goštauto 11, LT-01108 Vilnius, Lithuania \\ E-mail: renata@pfi.lt \\ ${ }^{\mathrm{b}}$ Materials Science Center and Faculty of Physics, Philipps-Universität Marburg, Renthof 5, 35032 Marburg, Germany
}

Received 7 December 2013; revised 7 January 2014; accepted 29 May 2014

\begin{abstract}
Thin GaAsBi layers and bismide-based multiple quantum structures were grown by migration-enhanced epitaxy onto $\mathrm{GaAs}(100)$ substrates at $140-240{ }^{\circ} \mathrm{C}$ temperatures. The Bi content in $\mathrm{GaAs}$, evaluated from high-resolution X-ray diffraction scans, varied from 2.5 to $10.3 \%$ depending on growth temperature, $\mathrm{Bi}$ and $\mathrm{As}$ atomic ratio as well as on the sequence of $\mathrm{Ga}$, $\mathrm{Bi}$, and As molecular supplies. The atomic force microscopy revealed a tendency of smoothening of the GaAsBi surface with substrate temperature decreasing. Transmission electron microscopy investigations evidenced high crystalline material quality of GaAsBi quantum wells and GaAs barriers.
\end{abstract}

Keywords: GaAsBi, migration-enhanced epitaxy, quantum wells

PACS: 81.05.Ea, 81.15.Hi, 81.07.Vb

\section{Introduction}

The dilute bismide GaAsBi has a number of interesting properties that make it potentially useful for applications in optoelectronics. It has been shown that bismuth incorporation produces a large reduction of the band gap of GaAs (up to $88 \mathrm{meV} / \% \mathrm{Bi}$ ) [1-4]. Moreover, $\mathrm{GaAsBi}$ is expected to be a key material for active layers of diode lasers with reduced temperature sensitivity of emission wavelength [5]. However, the applications of this new alloy are seriously hampered by technological difficulties of growing GaAsBi layers with a high Bi content, which mainly arise because of the tendency of bismuth to segregate and to form droplets on the surface. For arsenic to be substituted by much larger Bi atoms, extremely low growth temperatures and $\mathrm{As}_{2} / \mathrm{Ga}$ flux ratios close to 1 are essential in molecular beam epitaxy (MBE) growth. Unfortunately, a mere fulfilment of both these technological requirements does not necessarily guarantee a successful growth of GaAsBi layers with high crystalline quality and droplet-free surfaces.

In this work, GaAsBi layers were grown by another, related technique - migration-enhanced epitaxy (MEE) - a method proposed by Horikoshi et al. for growing epitaxial layers of $\mathrm{GaAs}$ and $\mathrm{AlGaAs}$ at temperatures below $300{ }^{\circ} \mathrm{C}[6$, th. The key to the growth of epitaxial GaAs at low temperatures is to minimize the excess of arsenic and to enhance the surface mobility of gallium adatoms. In MEE, Ga atoms are supplied on the growing surface under As-free conditions or at very low As beam pressures. Under these conditions, $\mathrm{Ga}$ atoms are expected to migrate along the surface and to find stable sites even at significantly reduced growth temperatures. High structural quality of Be-doped GaAs grown by MEE at a temperature of about $300^{\circ} \mathrm{C}$ was evidenced by a significant photoluminescence signal [8], which is typically absent when this material is grown at low temperatures by a conventional MBE technique [9].

\section{Sample preparation}

Thin GaAsBi layers and GaAsBi/GaAs multiple quantum wells (MQWs) were grown on semi-insulating GaAs (100) substrates using a SVT-A MBE reactor equipped with metallic $\mathrm{Ga}$ and $\mathrm{Bi}$ sources as well as with a two-zone arsenic cracker source to produce $\mathrm{As}_{2}$. The substrate temperature was monitored by thermocouple readings. Beam equivalent pressures (BEPs) of $\mathrm{Ga}, \mathrm{As}_{2}$, and $\mathrm{Bi}$ were measured by a retractable ion gauge. Surface adatom migration processes as well as the growth of GaAsBi layers were monitored in situ by observing reflection high-energy electron diffraction (RHEED) patterns and by recording their specular beam intensities. After native oxide removal, a 150-nm-thick GaAs buffer layer was grown at a substrate temperature of $560{ }^{\circ} \mathrm{C}$ and $\mathrm{As}_{2}$ and $\mathrm{Ga} \mathrm{BEP}$ ratio from 8 to 10 . The thickness of a bismide layer was designed to be below the critical thickness for structural relaxation through 
misfit dislocation formation. The MEE growth of 30-nm-thick GaAsBi layers and MQW structures was performed at substrate temperatures ranging from 140 to $280{ }^{\circ} \mathrm{C}$. The growth rate as evaluated from the RHEED intensity oscillation period was equal to $r_{\mathrm{g}} \approx 0.11 \mu \mathrm{m} / \mathrm{h}$. The Ga-atom flux was calculated from the formula

$$
F_{\mathrm{Ga}}=\frac{4 r_{\mathrm{g}}}{d^{3}},
$$

where $d$ is the lattice constant of GaAs. The factor of 4 comes out from the fact that the unit cell of GaAs contains $4 \mathrm{Ga}$ atoms or consists of two $\mathrm{Ga}$ (i. e. $2 \mathrm{Ga}$ atoms per monolayer) and two As atomic layers. The fluxes of group $\mathrm{V}$ atoms $F_{\mathrm{i}}(i=\mathrm{As}$ or $\mathrm{Bi}$ ) were determined as [10]

$$
F_{\mathrm{i}}=F_{\mathrm{Ga}} \frac{P_{\mathrm{i}} \cdot \eta_{\mathrm{Ga}}}{P_{\mathrm{Ga}} \cdot \eta_{\mathrm{i}}}\left(\frac{T_{\mathrm{i}} \cdot M_{\mathrm{Ga}}}{T_{\mathrm{Ga}} \cdot M_{\mathrm{i}}}\right)^{1 / 2} .
$$

Here $P_{\mathrm{i}}, T_{\mathrm{i}}, M_{\mathrm{i}}$, and $\eta_{i}$ are, respectively, BEPs, source temperatures, molecular masses, and ion gauge sensitivity coefficients for $\mathrm{As}_{2}$ and $\mathrm{Bi}$. It should be noted that due to specific position of the ion gauge in our MBE equipment, the ion gauge measurement of $\mathrm{BEPs}$ for $\mathrm{Bi}$ was not possible, thus the fluxes indicated for this element represent relative values only. From Eq. (1) the duration of Ga monolayer growth was determined as equal to about $9.5 \mathrm{~s}$; whereas the duration of the opening of arsenic source was prolonged to $12.5 \mathrm{~s}$ due to substitution of $1 \mathrm{ML}$ of As by Bi and reduced to about 0.75 (maximum) $\mathrm{As}_{2}$ sticking coefficient at temperatures used for the bismide growth [11]. On the other hand, the duration of Bi supply, which at used fluxes should be about $65 \mathrm{~s}$, was slightly shortened (to $58 \mathrm{~s}$ ) after considering a possible migration of $\mathrm{Bi}$ atoms from neighbouring layers. It was demonstrated in Ref. [12] that the lifetime of $\mathrm{Ga}$ atoms on the growing surface before their reaction with As is significantly increased when lowering the arsenic pressure. For this reason, the growth was interrupted for 5 seconds between the supplies of $\mathrm{Ga}$ and As atoms in order to enhance surface migration of $\mathrm{Ga}$ atoms. Three different sequences of group III and V atomic layer deposition have been used for GaAsBi layer growth: Bi atoms were supplied to every second, every third, and every fifth group V element atomic layer. It should be pointed out that the overall duration of each element supply during one GaAsBi monolayer growth cycle and different growth sequences remained unchanged. Figure 1 demonstrates the segment of the growth of the GaAsBi layer when Bi atoms have been supplied to every fifth As ML.

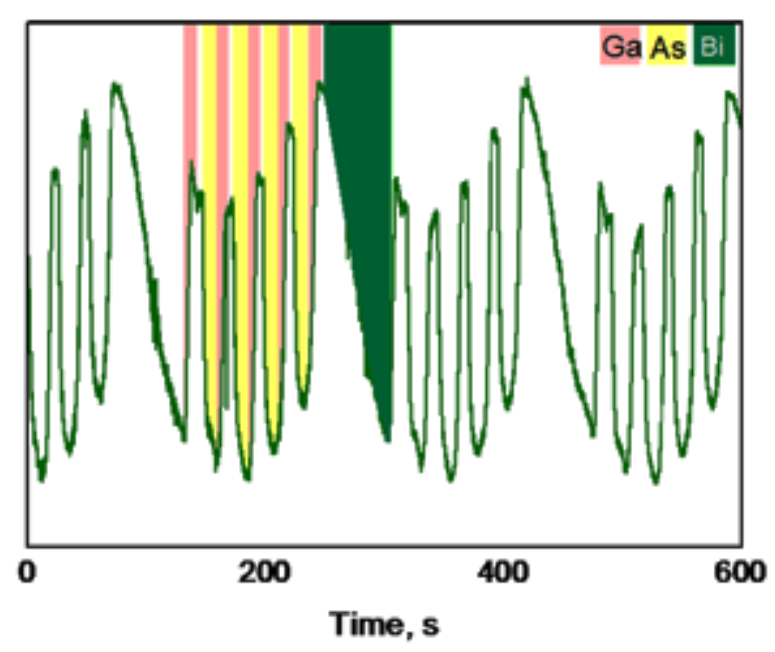

Fig. 1. The segment of specular spot intensity dependence on time measured during the growth of the GaAsBi layer. Bi atoms were supplied to every fifth As ML.

\section{Results and discussion}

The layers were fully strained (pseudomorphic) to the GaAs substrate. The Bi content in GaAsBi layers was determined by fitting high-resolution X-ray diffraction (XRD) $\omega / 2 \theta$ scans using Vegard's law and $\mathrm{GaBi}$ lattice constant of $6.324 \AA$ [13]. Figure 2 shows XRD scans of (004) reflex measured for several 30-nm-thick GaAsBi layers grown at two different temperatures and two Bi/As BEP ratios. As it was expected, the reduction of the growth temperature results in the increase

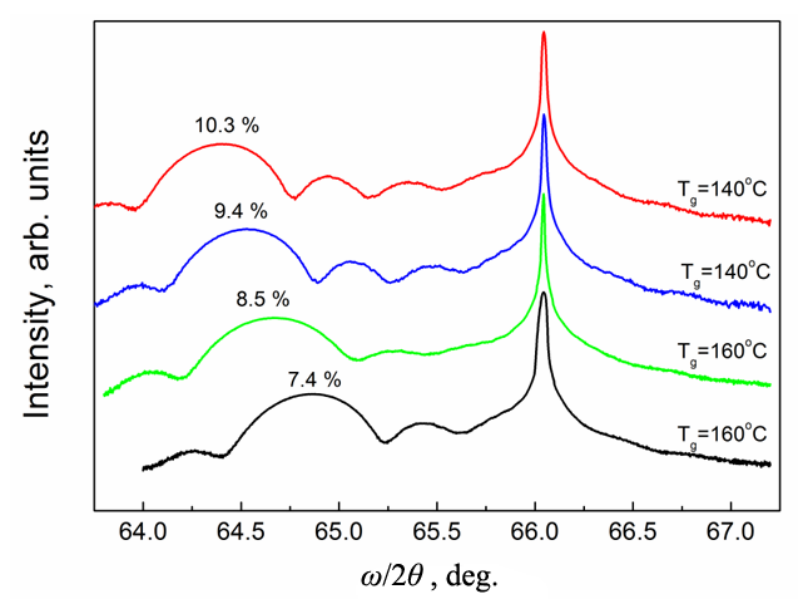

Fig. 2. $\omega-2 \theta \mathrm{X}$-ray diffraction scans of (004) reflex measured for GaAsBi layers grown at 140 and $160^{\circ} \mathrm{C}$ temperatures when supplying Bi atoms to every fifth (three bottom curves) and every third (top curve) group V element atomic layer. The lowest trace was measured on a layer grown at $\mathrm{Bi} /$ As atomic ratio of about 0.05 ; the remaining traces correspond to layers grown at $\mathrm{Bi} / \mathrm{As}$ atomic ratio of $\sim 0.065$. 
of Bi content. Moreover, the presence of well defined Pendellösung fringes indicates good crystalline quality and smooth $\mathrm{GaAsBi} / \mathrm{GaAs}$ interfaces even at the highest Bi content of about $10.3 \%$. Atomic force microscopy (AFM) images of the layers grown by MEE demonstrated smoother surfaces than in the case of GaAsBi grown by a conventional molecular beam epitaxy. The surface roughness of MEE-grown layers was in the range from 0.2 to $0.4 \mathrm{~nm}$ (scanned area of about $\left.8 \times 8 \mu \mathrm{m}^{2}\right)$ - two times smaller as compared with typical values for MBE-grown GaAsBi [14].

Bismuth incorporation into the GaAs lattice for three different growth cycles used in this study was slightly different. Most preferable conditions for $\mathrm{Bi}$ incorporation emerge when the Bi source is opened during every third group $\mathrm{V}$ element atomic layer growth. However, a larger $\mathrm{Bi}$ content at a given growth temperature and for a larger $\mathrm{Bi} /$ As beam ratio is achieved at the cost of inferior surface quality and droplet formation.

The dependence of Bi content in GaAsBi layers on $\mathrm{Bi} /$ As BEP ratio is presented in Fig. 3. All experimental points correspond to the case where Bi source was open when depositing every fifth group $\mathrm{V}$ element atomic layer. One can see from this Figure that both the decrease of substrate temperature and the increase of $\mathrm{Bi} / \mathrm{As} \mathrm{BEP}$ ratio lead to a larger incorporation of bismuth atoms into a growing layer. At larger $\mathrm{Bi} / \mathrm{As} \mathrm{BEP}$ ratios, the $B i$ content in a layer tends to saturate; this saturation is starting earlier at higher substrate temperatures. The saturation process is accompanied by the appearance of Bi droplets (of a few tens of nanometres in diameter) on the sample's surface.

The atomic force microscopy revealed the general tendency of smoothening of the GaAsBi surface with

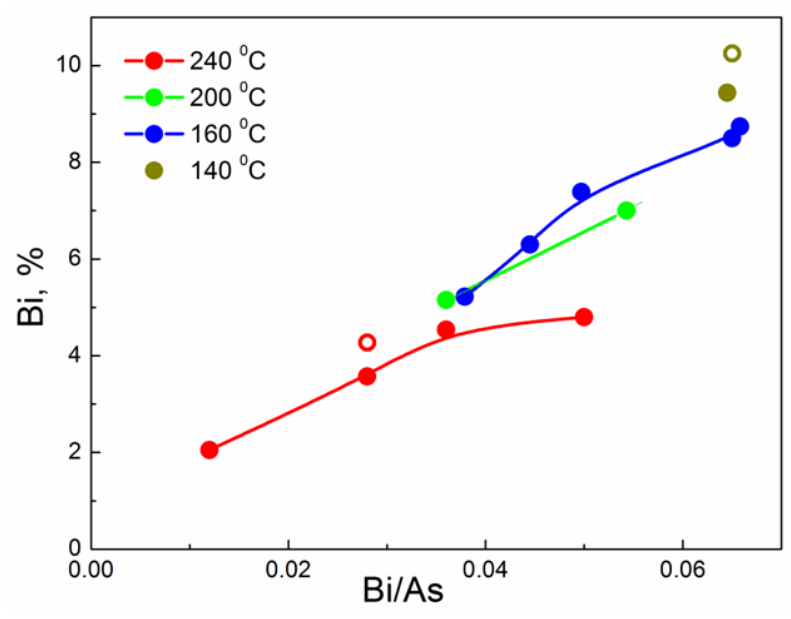

Fig. 3. Dependence of Bicontent in GaAsBilayers on Bi/As atomic ratio supplying $\mathrm{Bi}$ atoms to every fifth (full points) or every third (empty point) group $\mathrm{V}$ element atomic layer. decreasing of growth temperature (images are not presented in the paper). Small droplets of Bi (with a few tens of nanometres in diameter) have been observed on the surfaces of the majority of layers grown at substrate temperatures higher than $240{ }^{\circ} \mathrm{C}$. Meanwhile, the surfaces of $\mathrm{GaAsBi}$ layers grown at temperatures lower than $200^{\circ} \mathrm{C}$ were free from the droplets. Only AFM images of the samples grown with the largest Bi content at 140 and $160{ }^{\circ} \mathrm{C}$ demonstrated some small-scale surface irregularities. The similarity of those irregularities to the features on MBE-grown GaAsBi referred to in [14 allows us attribute them to the nuclei of a new monolayer [15].

The GaBiAs/GaAs MQW structure was grown at the temperature of $160{ }^{\circ} \mathrm{C}$ and consisted of four 5 -nm-thick GaAsBi quantum wells surrounded by 30-nm-wide GaAs barriers. The technological conditions for the MQW structure growth were selected attempting to achieve both a large Bi content and the lowest interface roughness. $(2 \times 1)$ and $(1 \times 3)$ surface reconstructions were observed during the growth of GaAsBi QWs and GaAs barriers, respectively. In Fig. 4 , chemically sensitive transmission electron microscopy

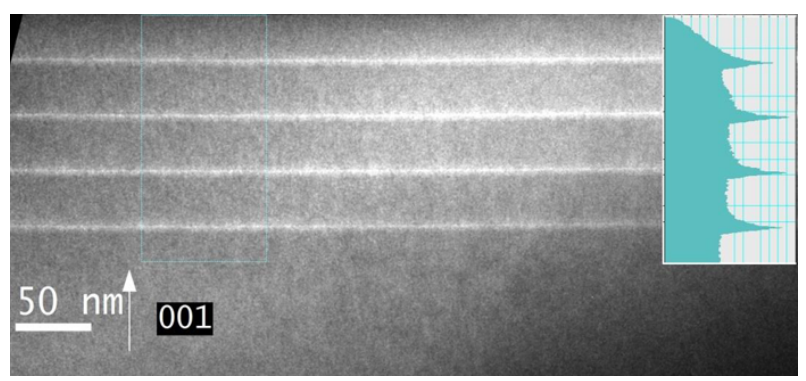

Fig. 4. Chemically sensitive (002) TEM dark field image of $\mathrm{Ga}(\mathrm{BiAs}) / \mathrm{GaAs}$ multiple quantum well structure and the line-scan across the TEM image.

(TEM) (002) dark field micrographs of this structure are shown together with a line-scan across the structure. The quantum wells exhibit a bright contrast with respect to the GaAs barrier. They all have a similar composition as well as width. The homogeneity of the composition in the growth plane is very good; there is, however, some segregation of $\mathrm{Bi}$ in the GaAs barrier. This can be concluded from the line-scan, which shows that the lower barrier/quantum well interface is much sharper than the upper quantum well/barrier interface. This segregation will in future be minimized by tuning the growth conditions.

\section{Conclusions}

In conclusion, $\mathrm{GaAsBi}$ layers and multiple quantum well structures have been grown on GaAs substrates 
by migration-enhanced epitaxy at temperatures as low as $140{ }^{\circ} \mathrm{C}$. Alloys with more than $10 \%$ of $\mathrm{Bi}-\mathrm{a}$ composition necessary for the applications in a $1.55 \mu \mathrm{m}$ optical communication window - were obtained. GaAsBi layers were of high structural uniformity and their surfaces were nearly free from Bi droplets. Some out-diffusion of bismuth into the growing GaAs barrier layer reduces the abruptness of $\mathrm{GaAsBi} / \mathrm{GaAs}$ interfaces; this problem could eventually be solved by optimizing the growth conditions or by growing additional diffusion barriers at these interfaces.

\section{Acknowledgement}

Support of the Research Council of Lithuania under grant No. VP1-3.1-ŠMM-07-K-01-058 (BISMIDAI) is gratefully acknowledged.

\section{References}

[1] S. Francoeur, M.J. Seong, A. Mascarenhas, S. Tixier, M. Adamcyk, and T. Tiedje, Band gap of GaAs $\mathrm{Bai}_{1-x} \mathrm{Bi}_{x}$ $0<x<3.6 \%$, Appl. Phys. Lett. 82(22), 3874-3876 (2003), http://dx.doi.org/10.1063/1.1581983

[2] B. Fluegel, S. Francoeur, A. Mascarenhas, S. Tixier, E.C. Young, and T. Tiedje, Giant spinorbit bowing in $\mathrm{GaAs}_{1-x} \mathrm{Bi}_{x}$, Phys. Rev. Lett. 97, 067205-1-4 (2006), http://dx.doi.org/10.1103/ PhysRevLett.97.067205

[3] V. Pačebutas, K. Bertulis, L. Dapkus, G. Aleksejenko, A. Krotkus, K.M. Yu, and W. Walukiewicz, Characterization of low-temperature molecularbeam-epitaxy grown GaBiAs layers, Semicond. Sci. Technol. 22, 819-823 (2007), http://dx.doi. org/10.1088/0268-1242/22/7/026

[4] K. Oe and H. Okamoto, New semiconductor alloy $\mathrm{GaAs}_{1-x} \mathrm{Bi}_{x}$ grown by metal organic vapor phase epitaxy, Jpn. J. Appl. Phys. 37, L1283-L1285 (1998), http://dx.doi.org/10.1143/JJAP.37.L1283

[5] K. Oe, Characteristics of semiconductor alloy $\mathrm{GaAs}_{1-r} \mathrm{Bi}_{w_{2}}$ J. Appl. Phys. 41, 2801-2806 (2002), http://dx.doi.org/10.1143/JJAP.41.2801

[6] Y. Horikoshi, M. Kawashima, and H. Yamaguchi, Migration-enhanced epitaxy of GaAs and AlGaAs,
Jpn. J. Appl. Phys. 27(2), 169-179 (1988), http:// dx.doi.org/10.1143/JJAP.27.169

[7] Y. Horikoshi, Migration-enhanced epitaxy of GaAs and AlGaAs, Semicond. Sci. Technol. 8, 10321051 (1993), http://dx.doi.org/10.1088/0268$1242 / 8 / 6 / 010$

[8] B. Tadayon, S. Tadayon, W.J. Schaff, M.G. Spencer, G.L. Harris, P.J. Tasker, C.E.C. Wood, and L.F. Eastman, Reduction of Be diffusion in GaAs by migration-enhanced epitaxy, Appl. Phys. Lett. 55, 59-61 (1990), http://dx.doi.org/10.1063/1.101753

[9] F.W. Smith, A.R. Calawa, C.-L. Chen, M.J. Manfera, and L.J. Mahoney, New MBE buffer used to eliminate backgating in GaAs MESFETs, IEEE Electron Dev. Lett. 9, 77-80 (1988), http://dx.doi. org/10.1109/55.2046

[10] G.J. Davies and D. Williams, The Technology and Physics of Molecular Beam Epitaxy, ed. E.H.C. Parker (Plenum Press, New York, 1985), ISBN-13: 978-0306418600

[11] V.V. Preobrazhenskii, M.A. Putyato, O.P. Pchelyakov, and B.R. Semyagin, Experimental determination of the incorporation factor of As4 during molecular beam epitaxy of GaAs, I. Cryst. Growth 201/202, 170-173 (1999), http://dx.doi. org/10.1016/S0022-0248(98)01308-6

[12]S. Nagata and T. Tanaka, Self-masking selective epitaxy by molecular-beam method, I. Appl. Phys. 48, 940-942 (1977), http://dx.doi. org/10.1063/1.323712

[13] A. Janotti, S.-H. Wei, and S.B. Zhang, Theoretical study of the effects of isovalent coalloying of $\mathrm{Bi}$ and $\mathrm{N}$ in GaAs, Phys. Rev. B 65, 115203-1-5 (2002), http://link.aps.org/doi/10.1103/PhysRevB. 65.115203

[14]X. Lu, D.A. Beaton, R.B. Lewis, T. Tiedje, and M.B. Whitwick, Effect of molecular beam epitaxy growth conditions on the Bi content of $\mathrm{GaAs}_{1-x} \mathrm{Bi}_{{ }_{2}}$ Appl. Phys. Lett. 92, 192110-1-3 (2008), http:// dx.doi.org/10.1063/1.2918844

[15] B.A. Joyce, D.D. Vvedensky, T.S. Jones, M. Itoh, G.R. Bell, and J.G. Belk, In situ studies of III-V semiconductor film growth by molecular beam epitaxy, J. Cryst. Growth 201/202, 106-112 (1999), http://dx.doi.org/10.1016/S0022-0248(98)01295-0 


\title{
PLONŲJŲ EPITAKSINIŲ GaAsBi SLUOKSNIŲ AUGINIMAS SKATINANT ATOMŲ MIGRACIJA
}

\author{
R. Butkutè ${ }^{\text {a }}$, V. Pačebutas ${ }^{\text {a }}$, A. Krotkus ${ }^{\text {a }}$, N. Knaub ${ }^{\text {b }}$, K. Volz ${ }^{\text {b }}$ \\ ${ }^{a}$ Fiziniu ir technologijos moksly centras, Vilnius, Lietuva \\ ${ }^{\mathrm{b}}$ Marburgo Phillips universiteto Fizikos fakulteto Medžiagotyros centras, Marburgas, Vokietija
}

\begin{abstract}
Santrauka
Straipsnyje pateikiama plonųjų GaAsBi sluoksnių ir kvantinių darinių auginimo, pasitelkiant migraciją paskatinančią epitaksiją, studija. Darbe tiriama ir analizuojama technologinių sąlygų ịtaka praskiestujų bismidu sluoksnių ir kvantinių darinių kristalinei sandarai bei paviršiaus šiurkštumui. Ploni GaAsBi sluoksniai ir dariniai buvo auginami ant GaAs(100) padèklų esant $140-240{ }^{\circ} \mathrm{C}$ temperatūrai. Bi koncentracija, ivertinta matuojant didelès skyros rentgeno spindulių difrakcijos (004) plokštumos atspindžio
\end{abstract}

smailès svyravimo kreives, priklausė nuo pasirinktos auginimo temperatūros, $\mathrm{Bi}$ ir As srautų santykio bei Ga-Bi-As atominių sluoksnių užpildos sekos ir kito nuo 2,5 iki 10,3 \%. Atominių jègų mikroskopiniai tyrimai atskleidè GaAsBi sluoksnių paviršiaus šiurkštumo mažèjimo tendenciją (mažèjant auginimo temperatūrai). Peršviečiančiojo elektronų mikroskopo vaizdai patvirtino aukštą plonų bismidų sluoksnių ir kvantinių darinių kristalinę kokybę, homogenišką Bi pasiskirstymą ir aštrias ribas tarp GaAsBi kvantinių duobių ir GaAs barjerų. 